\title{
Levels of polybrominated diphenyl ether congeners in the serum of dogs as a potential indicator of environmental pollution and human exposure - short communication
}

\author{
Emil Srebočan ${ }^{1}$, Renata Barić Rafaj², Andreja Prevendar Crnićc1*, \\ and Vladimir Mrljak ${ }^{3}$ \\ ${ }^{1}$ Department of Pharmacology and Toxicology, Faculty of Veterinary Medicine, University of Zagreb, \\ Zagreb, Croatia \\ ${ }^{2}$ Department of Chemistry and Biochemistry, Faculty of Veterinary Medicine, University of Zagreb, \\ Zagreb, Croatia \\ ${ }^{3}$ Clinic for Internal Diseases, Faculty of Veterinary Medicine, University of Zagreb, Zagreb, Croatia
}

\begin{abstract}
SREBOČAN, E., R. BARIĆ RAFAJ, A. PREVENDAR CRNIĆ, V. MRLJAK: Levels of polybrominated diphenyl ether congeners in the serum of dogs as a potential indicator of environmental pollution and human exposure - short communication. Vet. arhiv 89, 247-255, 2019.
\end{abstract}

\section{ABSTRACT}

Brominated flame retardants (BFRs) have been used for the last 60 years, but their negative effects on animals and possibly humans has only been observed in the last 20 years, and they have been intensively studied since then. The widespread presence of flame retardant in the indoor environment make domestic pets, who share the human environment and even food, perfect indicators for biomonitoring studies. Among brominated flame retardants, polybrominated diphenyl ethers (BDE) have received the most attention. We measured the concentrations of some polybrominated diphenyl ether congeners (BDE 28, BDE 47, BDE 66, BDE 100, BDE 99, BDE 85, BDE 154, BDE 153 and BDE 183) in the serum of 20 obese and 20 normal house dogs. We found no statistical differences between the concentrations of any BDE congeners in either group of dogs. Total average values were $0.0190 \pm 0.0302 \mathrm{ng} / \mathrm{g}$ and $0.0112 \pm 0.0091 \mathrm{ng} / \mathrm{g}$, respectively. BDE 47 and BDE $99 \mathrm{were}$ predominant congeners in both groups of dogs. The correlation between serum concentrations of total BDE-s and thyroxine and thyroid-stimulating hormone concentrations were not significant.

Key words: brominated flame retardants; contamination; pets; serum; indoor environment; persistent organic pollutants

\footnotetext{
${ }^{*}$ Corresponding author:

Andreja Prevendar Crnić, DVM, PhD, Department of Pharmacology and Toxicology, Faculty of Veterinary Medicine, University of Zagreb, Heinzelova 55, 10000 Zagreb, Croatia; Phone: +385 12390 160; E-mail: apcrnic@vef.hr
} 
E. Srebočan et al.: Levels of polybrominated diphenyl ether congeners in the serumof dogs as a potential indicator of environmental pollution and human exposure

\section{Introduction}

Brominated flame retardants (BFRs) have been widely used in polymers to slow the combustion of these materials. They can migrate out of the products to which they were added and enter the environment, and consequently they have been detected in a variety of samples, including the atmosphere, lake and sea sediments, human and pet (dogs, cats) serum and food, cow fat and milk, moose livers, arctic fox and polar bear adipose tissue, bald eagles and herring gull eggs (VENIER and HITES, 2011; GUPTA, 2012). Because of their unique physicochemical and biochemical properties, they persist and pervade every component of the global ecosystem, and have the potential of bioaccumulation and biomagnification, leading to exposure to animals and humans, usually in low concentrations with negative health effects (HARRAD and DIAMOND, 2006; VENIER and HITES, 2011; GUPTA, 2012). The suggested mechanism of toxicity for BFRs is disruption of thyroid hormone homeostasis. When BFRs enter the circulation they can displace thyroxine (T4) from serum binding proteins such as transthyretin (TTR). The resulting free $\mathrm{T} 4$ will be subjected to hepatic metabolism and elimination. Reduced circulating T4 levels trigger the hypothalamic-pituitary axis to synthesize and secrete more T4 by the thyroid gland. BFRs bound to TTR along with thyroxine will reach target organs including the brain, where they may bind to TH receptors to effect a biological/ toxicological response. After they enter, the liver activates nuclear receptors, BFRs initiate transcription of xsenobiotic-metabolizing enzymes for T4. Influx transporters further increase the T4 uptake and metabolism. Efflux transporters eliminate T4 or its conjugates from the liver into either the serum or bile (KODAVANTI and CURRAS-COLLAZO, 2010). Of the BFR-s, polybrominated diphenyl ethers (BDEs) have received the most attention because of their frequent use in the indoor environment, which makes pets, who share the human environment and even food, a perfect indicator for biomonitoring studies, since biomonitoring studies of people are difficult (VENIER and HITES, 2011). The objective of this study was to determine the presence and amount of BDE congeners (BDE 28, BDE 47, BDE 66, BDE 100, BDE 99, BDE 85, BDE 154, BDE 153 and BDE 183) in the serum of 20 obese and 20 normal dogs in Croatia, who share the human environment and even their food.

\section{Materials and methods}

The assessment of the nutritional condition of 40 dogs was based on a 5-point body condition scoring (BCS) system (LAFLAMME, 1997). A single investigator assigned the dog to either lean (BCS 3), overweight (BCS 4) or obese (BCS 5) groups. In addition, the weight of the dogs was compared with the standard weight for the breed. The overweight dogs' weight was $15-30 \%$ above the ideal and the obese dogs weight was $>30 \%$ of the ideal (BURKHOLDER and TOLL, 2000). 
E. Srebočan et al.: Levels of polybrominated diphenyl ether congeners in the serumof dogs as a potential indicator of environmental pollution and human exposure

BDEs were analysed in the serum of 20 obese and 20 normal house dogs by gas chromatography/high-resolution mass spectrometry (GC/HRMS), using isotope dilution for the quantitation as described in the EPA1614A (ANONYM., 2010).

Serum samples were accurately weighed in an air-tight glass vial and $2 \mathrm{ng}$ of $13 \mathrm{C} 12$ labelled analogues of every target BDE (MBDE-MXFS; Wellington Laboratories, Guelph, Ontario) was added using a microsyringe (Hamilton, Reno, Nevada) and thoroughly mixed for at least 1 minute. Then an amount of formic acid $(\geq 90 \%$, Analar NORMAPUR; VWR International, Radnor, Pennsylvania) equivalent to the serum volume was added to the vial and left to react. After 20 minutes an equivalent amount of MilliQ water (Millipore, Brussels) was added to stop the reaction. Within this time a C18 SPE cartridge (ISOLUTE C18 $100 \mathrm{mg} / 3 \mathrm{~mL}$; Biotage, Uppsala) was conditioned in a Flashvac extraction vacuum manifold (Biotage, Uppsala) with $6 \mathrm{~mL}$ of methanol (Dioxins analysis grade; Biosolve, Valkenswaard) and $6 \mathrm{~mL}$ of MilliQ water at the rhythm of 1 drop per second (the cartridges were capped between the additions to avoid contamination from the laboratory air). Then, the sample was transferred to the cartridge and the vial rinsed twice with MilliQ water. Next, the C18 cartridge was dried under nitrogen flow (6.0 grade; Westfalen AG, Münster) for 1 hour and the PBDEs were eluted with $9 \mathrm{~mL}$ of $\mathrm{n}$-hexane (Dioxins analysis grade; Biosolve, Valkenswaard) in a glass vial. Finally, the sample was evaporated to $100 \mu \mathrm{L}$ under nitrogen flow and closed air-tight.

The purification was carried out using a basic alumina SPE cartridge (ISOLUTE AL-B $100 \mathrm{mg} / 1 \mathrm{~mL}$; Biotage, Uppsala) containing $100 \mathrm{mg}$ of silica, acidified with 44\% of H2SO4 ( $\geq 95-97 \%$, Analar NORMAPUR; VWR International, Radnor, Pennsylvania) and $100 \mathrm{mg}$ of $\mathrm{Na}_{2} \mathrm{SO}_{4}$ (anhydrous, Analar NORMAPUR; VWR International, Radnor, Pennsylvania). This cartridge was conditioned with $2 \mathrm{~mL}$ of a 1:1 mixture of n-hexane:dichloromethane and $2 \mathrm{~mL}$ of $\mathrm{n}$-hexane. Then, the sample was transferred to the cartridge and the vial rinsed with 2 times $200 \mu \mathrm{L}$ of $\mathrm{n}$-hexane. The BDEs were eluted with 2 volumes of a 1:1 mix of $n$-hexane:dichloromethane in a glass vial containing 4 $\mu \mathrm{L}$ of n-nonane ( $\geq 99 \%$; Sigma-Aldrich, St. Louis) used as keeper. Finally, the sample was concentrated to $4 \mu \mathrm{L}$ under nitrogen flow and spiked with $2 \mathrm{ng}$ of $13 \mathrm{C} 12$ labelled recovery standard (MBDE-MXFR; Wellington Laboratories, Guelph, Ontario) to reach a final volume of $6 \mu \mathrm{L}$.

Two $\mu \mathrm{L}$ of the sample was injected into a splitless injector, held at $275^{\circ} \mathrm{C}$ with a 1 minute splitless time. The separation was achieved in a DB-5ht gas chromatography column $(15 \mathrm{~m} \times 0.25 \mathrm{~mm} \times 0.1 \mu \mathrm{m}$; Agilent Technologies, Palo Alto, California $)$ coupled to an Autospec Premier sector mass spectrometer (Waters Corporation, Milford, Massachusetts) set at 10000 mass resolution. The analytes were eluted with a $1 \mathrm{~mL} /$ min helium flow (6.0 grade; L'Air Liquide SA, Paris) and the following temperature program: $80{ }^{\circ} \mathrm{C}$ for 2 minutes, ramped to $170{ }^{\circ} \mathrm{C}$ at $30{ }^{\circ} \mathrm{C} / \mathrm{min}$, then to $210{ }^{\circ} \mathrm{C}$ at $3{ }^{\circ} \mathrm{C} /$ 
E. Srebočan et al.: Levels of polybrominated diphenyl ether congeners in the serumof dogs as a potential indicator of environmental pollution and human exposure

min, to $270{ }^{\circ} \mathrm{C}$ at $5{ }^{\circ} \mathrm{C} / \mathrm{min}$ and finally to $380{ }^{\circ} \mathrm{C}$ at $70{ }^{\circ} \mathrm{C} / \mathrm{min}$, which was held for 2 min. Compounds were detected in SIM (Selected Ion Monitoring) mode according to the mass list in Table 1. Two ions were monitored for every BDE and their ion ratios measured in order to ensure specificity (ANONYM., 2010). Prior to the sample injection, the instrument was calibrated with a commercial 5 point calibration curve (BDE-CVS-F; Wellington Laboratories, Guelph, Ontario) and the procedural blank was analysed to check the contamination level.

Table 1. List of ions $(\mathrm{m} / \mathrm{z})$ used for the analysis of BDEs

\begin{tabular}{|l|c|c|c|c|}
\hline Congener & $\begin{array}{c}\text { Native } \\
\text { Quantitation }\end{array}$ & $\begin{array}{c}\text { Native } \\
\text { Qualification }\end{array}$ & $\begin{array}{c}{ }^{13} \mathrm{C}_{12} \text { labelled } \\
\text { Quantitation }\end{array}$ & $\begin{array}{c}{ }^{13} \mathrm{C}_{12} \text { labelled } \\
\text { Qualification }\end{array}$ \\
\hline BDE-28 & 405.8027 & 407.8002 & 417.8429 & 419.8409 \\
\hline BDE-47 & 483.7132 & 485.7111 & 497.7514 & 499.7493 \\
\hline BDE-66 & 483.7132 & 485.7111 & - & - \\
\hline BDE-77* & - & - & 497.7514 & 499.7493 \\
\hline BDE-100 & 563.6216 & 565.6196 & 575.6619 & 577.6598 \\
\hline BDE-99 & 563.6216 & 565.6196 & 575.6619 & 577.6598 \\
\hline BDE-85 & 563.6216 & 565.6196 & - & - \\
\hline BDE-154 & 483.7132 & 485.7111 & 497.7514 & 499.7493 \\
\hline BDE-153 & 483.7132 & 485.7111 & 497.7514 & 499.7493 \\
\hline BDE-138* & - & - & 497.7514 & 499.7493 \\
\hline BDE-183 & 563.6216 & 565.6196 & 575.6619 & 577.6598 \\
\hline
\end{tabular}

*are used as recovery standards

Validation was carried out by analysing 2 samples 3 times at 3 different levels (12.5, 25 and 100 pg/g serum) as recommended in the European Food and Feed Regulations (ANONYM., 2017; ANONYM., 2009). The validation samples were made with foetal bovine serum (Sigma-Aldrich, St. Louis) spiked with PBDEs (BDE-MXF; Wellington Laboratories, Guelph, Ontario) at the levels of interest then analysed using the procedure described. The LOQs were determined using the European LOQs guideline for contaminants (WENZL et al., 2016). The blank approach from the dioxins chapter was used for the PBDEs present in the procedural blanks (BDE 47, 100 and 99) and the signal to noise approach for the remaining (BDE 28, 66, 85, 154, 153 and 183). Low LOQs $(0.2-4.0 \mathrm{pg} / \mathrm{g})$ were achieved by taking precautions to avoid contamination, and the concentration factor in the injection vial. The expanded uncertainties $(8-18 \%)$ were calculated using the top-down approach, as described in the European Measurement Uncertainty Guidelines for dioxins and PCBs (EPPE et al., 2017) using a coverage factor of 2 .

Thyroxine and thyroid-stimulating hormone (TSH) concentrations were measured in the sera by solid-phase, two-site chemiluminescent immunometric canine specific 
E. Srebočan et al.: Levels of polybrominated diphenyl ether congeners in the serumof dogs as a potential indicator of environmental pollution and human exposure

tests, using an Immulite 1000 automatic system (Siemens, Hamburg, Germany). The results were analysed by the Statistica 13.2 computer software. Measured concentrations were not normally distributed (Shapiro-Wilk W test; $\mathrm{p}<0.05$ ), and a statistical difference was determined by the Mann-Whitney $U$ test; $p<0.05$ ). For correlations assessment, the Spearman Rank Order Correlation was used. The study protocol was approved by the Ethics Committee for Animal Experimentation, of the Faculty of Veterinary Medicine, University of Zagreb, Croatia (No. 251-61-01/139-16-1). All dog owners gave written informed consent before entering the study.

\section{Results}

Concentrations of BDE congeners (BDE 28, BDE 47, BDE 66, BDE 100, BDE 99, BDE 85, BDE 154, BDE 153 and BDE 183) were measured in the serum of 20 obese and 20 normal house dogs, and are presented in Tables 2 and 3 (middle bound).

Table 2. Descriptive statistics of concentrations of some polybrominated diphenyl ethers (ng/g serum) in obese house dogs

\begin{tabular}{|l|c|c|c|c|c|c|c|}
\hline Congener & $\mathrm{N}$ & Average & Median & Sum & Min & Max & SD \\
\hline BDE-28 & 20 & 0.0004 & 0.0004 & 0.0080 & 0.0004 & 0.0004 & 0.0000 \\
\hline BDE-47 & 20 & 0.0097 & 0.0020 & 0.1938 & 0.0020 & 0.0669 & 0.0178 \\
\hline BDE-66 & 20 & 0.0004 & 0.0004 & 0.0080 & 0.0004 & 0.0004 & 0.0000 \\
\hline BDE-100 & 20 & 0.0013 & 0.0005 & 0.0257 & 0.0005 & 0.0106 & 0.0023 \\
\hline BDE-99 & 20 & 0.0035 & 0.0010 & 0.0700 & 0.0010 & 0.0283 & 0.0062 \\
\hline BDE-85 & 20 & 0.0005 & 0.0004 & 0.0092 & 0.0004 & 0.0012 & 0.0002 \\
\hline BDE-154 & 20 & 0.0004 & 0.0004 & 0.0086 & 0.0004 & 0.0010 & 0.0001 \\
\hline BDE-153 & 20 & 0.0007 & 0.0004 & 0.0138 & 0.0004 & 0.0049 & 0.0010 \\
\hline BDE-183 & 20 & 0.0021 & 0.0004 & 0.0423 & 0.0004 & 0.0147 & 0.0039 \\
\hline
\end{tabular}

Table 3. Descriptive statistics of concentrations of some polybrominated diphenyl ethers (ng/g serum) in normal house dogs

\begin{tabular}{|l|c|c|c|c|c|c|c|}
\hline Congener & $\mathrm{N}$ & Average & Median & Sum & Min & Max & SD \\
\hline BDE-28 & 20 & 0.0004 & 0.0004 & 0.0080 & 0.0004 & 0.0004 & 0.0000 \\
\hline BDE-47 & 20 & 0.0047 & 0.0020 & 0.0939 & 0.0020 & 0.0209 & 0.0047 \\
\hline BDE-66 & 20 & 0.0004 & 0.0004 & 0.0080 & 0.0004 & 0.0004 & 0.0000 \\
\hline BDE-100 & 20 & 0.0007 & 0.0005 & 0.0142 & 0.0005 & 0.0033 & 0.0007 \\
\hline BDE-99 & 20 & 0.0020 & 0.0010 & 0.0397 & 0.0010 & 0.0117 & 0.0025 \\
\hline BDE-85 & 20 & 0.0005 & 0.0004 & 0.0095 & 0.0004 & 0.0014 & 0.0002 \\
\hline BDE-154 & 20 & 0.0004 & 0.0004 & 0.0080 & 0.0004 & 0.0004 & 0.0000 \\
\hline BDE-153 & 20 & 0.0014 & 0.0004 & 0.0288 & 0.0004 & 0.0166 & 0.0036 \\
\hline BDE-183 & 20 & 0.0007 & 0.0004 & 0.0132 & 0.0004 & 0.0024 & 0.0006 \\
\hline
\end{tabular}


E. Srebočan et al.: Levels of polybrominated diphenyl ether congeners in the serumof dogs as a potential indicator of environmental pollution and human exposure

Table 4. Descriptive statistics of thyroxine (T4) and thyroid-stimulating hormone (TSH) serum concentrations $(\mathrm{nmol} / \mathrm{L})$ of obese $(\mathrm{n}=20)$ and normal dogs

\begin{tabular}{|l|c|c|c|c|}
\hline \multirow{2}{*}{} & \multicolumn{4}{|c|}{ Descriptive statistics } \\
\cline { 2 - 5 } & Mean & Min & Max & SD \\
\hline T4 normal house dogs & 1.3756 & 0.2000 & 2.8100 & 0.5905 \\
\hline TSH normal house dogs & 0.2385 & 0.0420 & 1.2200 & 0.2650 \\
\hline T4 obese house dogs & 1.9869 & 0.6820 & 3.1700 & 0.6099 \\
\hline TSH obese house dogs & 0.1467 & 0.0300 & 0.3990 & 0.0992 \\
\hline
\end{tabular}

Table 4 presents descriptive statistics of the thyroxine and thyroid-stimulating hormone (TSH) concentrations of obese and normal dogs.

Table 5. Descriptive statistics of concentration sum of all congeners (ng/g serum) in obese and normal house dogs

\begin{tabular}{|l|c|c|c|c|c|c|c|}
\hline & $\mathrm{N}$ & Average & Median & Sum & Min & Max & SD \\
\hline Obese house dogs & 20 & 0.0190 & 0.0084 & 0.3794 & 0.0059 & 0.1275 & 0.0302 \\
\hline Normal house dogS & 20 & 0.0112 & 0.0062 & 0.2234 & 0.0059 & 0.0400 & 0.0091 \\
\hline
\end{tabular}

The dogs were of various ages, sexes and weights. We found no statistical differences between concentrations of total BDE-s between the groups of dogs, although the obese dogs had slightly higher concentrations. Total average values were $0.0190 \pm 0.0302 \mathrm{ng}$ g-1 and $0.0112 \pm 0.0091 \mathrm{ng}$ g-1, respectively (Table 5).

DE 47 and BDE 99 were the predominant congeners in both groups of dogs. Tendencies towards a negative association between concentrations of total BDE-s and thyroxine ( $\mathrm{r}=-0.31$, n.s.), as well as a positive association between concentrations of total BDE-s and TSH hormone concentrations $(r=0.032$, n.s. $)$ were observed in the obese dogs.

\section{Discussion}

Since Croatia adopted the Stockholm Convention on persistent organic pollutants (POPs), it has the obligation to draw up a plan for implementation of the Convention, which was completed this year through the Ministry of Environment and Energy. Considering this, we investigated the presence of some BDE congeners in pets who share the human environment and even their food. Average and median total BDE concentrations in our dogs were considerably lower than those in a US study (average $3.96 \pm 2.23 \mathrm{ng} / \mathrm{g}$; median $1.17 \mathrm{ng} / \mathrm{g}$, although in the US study only seven congeners were measured (VENIER and HITES, 2011). It is important to stress that these authors found that BDE 209 was the most abundant congener in the dog food. Similar results were also 
E. Srebočan et al.: Levels of polybrominated diphenyl ether congeners in the serumof dogs as a potential indicator of environmental pollution and human exposure

obtained for cats in a US study (young cats $4.3 \pm 1.5 \mathrm{ng} / \mathrm{g}$ (median 3.5); old euthyroid cats $10.5 \pm 3.5 \mathrm{ng} / \mathrm{g}$ (median 5.9); and old hyperthyroid cats $12.7 \pm 3.9 \mathrm{ng} / \mathrm{g}$ (median 6.2) (DYE et al., 2007). Cats usually have higher concentrations of contaminants present in the air, such as various retardants, which bind with dust, because they lick themselves much more than dogs (NOMIYAMA et al., 2017). Another source of contamination is food. The higher concentration of BDEs in obese dogs in our study suggests that dogs might accumulate these chemicals mainly through their diet, since daily feeding portions are larger in obese dogs than in normal dogs. It is also possible that species-specific metabolic capacity for BDEs is the cause of this difference (MIZUKAWA et al., 2017). In cats there were indications of an association between elevated BDE concentrations and hyperthyroidism (NORRGRAN et al., 2015), which we did not find in our study. We did not measure metabolites of BDE-s, but hydroxylated BDEs would probably correlate better than the parent compounds as they are more potent TH disruptors than the parent compounds (CHEVRIER, 2013). All this may be extrapolated to humans. As far as we know, this is the first report on BDE presence in biological material in Croatia.

\section{Acknowledgements}

This study (the experimental part) was supported through the Development Fund of the University of Zagreb. Publishing was supported through the FP7 project "Upgrading the research performance in molecular medicine at the Faculty of Veterinary Medicine University of Zagreb" (grant agreement no: 621394).

\section{References}

ANONYMOUS (2009): (EC) 152/2009 of 27 January 2009. Laying down the methods of sampling and analysis for the official control of feed. Official Journal of the European Union.

ANONYMOUS (2010): Method 1614A. Brominated diphenyl ethers in water, soil, sediment and tissue by HRGC/HRMS.

ANONYMOUS (2017) 2017/644 of 5 April 2017. Laying down methods of sampling and analysis for the control of levels of dioxins, dioxin-like PCBs and non-dioxin-like PCBs in certain foodstuffs. Official Journal of the European Union.

DOI: $10.3403 / 30198711$

BURKHOLDER, W. J., P. W. TOLL (2000): Obesity. In: Small Animal Clinical Nutrition, $4^{\text {th }}$ ed. (Hand, M. S., C. D. Thatcher, R. L. Reimillard, P. Roudebush, L. D. Lewis, Eds.), Mark Morris Institute, Topeka, Kansas, pp. 401-430.

CHEVRIER, J. (2013): Invited commentary: Maternal plasma polybrominated diphenyl ethers and thyroid hormones - challenges and opportunities. Am. J. Epidemiol. 178, 714-719.

DOI: $10.1093 /$ aje/kwt138

EPPE, G., A. SCHAECHTELE, J. HAEDRICH, A FERNANDES (2017): Guidance Document on Measurement Uncertainty for Laboratories performing PCDD/F and PCB analysis using 
E. Srebočan et al.: Levels of polybrominated diphenyl ether congeners in the serumof dogs as a potential indicator of environmental pollution and human exposure

Isotope Dilution Mass Spectrometry. Working Group for Measurement Uncertainty in PCDD/F and PCB Analysis - 2017.

DYE, J. A., M. VENIER, Z. GYAN, C. R. WARD, R. A. HITES, R. S. BIRNBAUM (2007): Elevated PBDE levels in pet cats: Sentinels for humans? Eviron. Sci. Technol. 41, 6350-6356. DOI: $10.1021 / \mathrm{es} 0708159$

GUPTA, R. C. (2012): Brominated flame retardants and perfluorinated chemicals. In: Veterinary Toxicology Basic and Clinical Principles, $2^{\text {nd }}$ ed. (Gupta, R. C., Ed.), Academic Press Elsevier Inc, London, Waltham, Sad Diego, pp. 810-823.

DOI: $10.1016 / \mathrm{b} 978-0-12-385926-6.00075-2$

HARRAD, S. J., M. L. DIAMOND (2006): Exposure to polybrominated diphenyl ethers (PBDEs) and polychlorinated diphenyls (PCBs): Current and future scenarios. Atmos. Environ. 40, 1187-1188.

DOI: 10.1016/j.atmosenv.2005.10.006

KODAVANTI, P. R. S., M. C. CURRAS-COLLAZO (2010): Neuroendocrine actions of organohalogens: thyroid hormones, arginine vasopressin, and neuroplasticity. Front. Neurochrinol. 31, 479-496.

DOI: 10.1016/j.yfrne.2010.06.005

LAFLAMME, D. (1997): Development and validation of a body condition score system for dogs. Canine Pract. 22, 10-5.

MIZUKAWA, H., K. NOMIYAMA, S. NAKATSU, M. YAMAMOTO, M. ISHIZUKA, Y. IKENAKA, S. M. M. NAKAYAMA, S. TANABE (2017): Anthropogenic and Naturally Produced Brominated Phenols in Pet Blood and Pet Food in Japan. Environ. Sci. Technol. 51, 11354-11362.

DOI: $10.1021 /$ acs.est.7b01009

NOMIYAMA, S. K., K. TAKAGUCHI, H. MIZUKAWA, Y. NAGANO, T. OSHIHOI, S. NAKATSU, T. KUNISUE, S. TANABE (2017): Species - and tissue-specific profiles of polybrominated diphenyl ethers and their hydroxylated and methoxylated derivatives in cats and dogs. Environ. Sci. Technol. 51, 5811-5819.

DOI: $10.1021 /$ acs.est.7b01262

NORRGRAN, J., B. JONES, A. BIGNERT, I. ATHANASSIADIS, A. BERGMAN (2015): Higher PBDE serum concentrations may be associated with feline hyoerthyroidism in Swedish cats. Environ. Sci. Technol. 49, 5107-5114.

DOI: $10.1021 /$ acs.est.5b00234

VENIER, M., R. A. HITES (2011): Flame retardants in the serum of pet dogs and in their food. Eviron. Sci. Technol. 45, 4602-4608.

DOI: $10.1021 /$ es 1043529 
E. Srebočan et al.: Levels of polybrominated diphenyl ether congeners in the serumof dogs as a potential indicator of environmental pollution and human exposure

WENZL, T., J. HAEDRICH, A. SCHAECHTELE, P. ROBOUCH, J. STROKA (2016): Guidance Document on the Estimation of LOD and LOQ for Measurements in the Field of Contaminants in Food and Feed. Publications Office of the European Union.

Received: 18 September 2017

Accepted: 17 May 2018

\section{SREBOČAN, E., R. BARIĆ RAFAJ, A. PREVENDAR CRNIĆ, V. MRLJAK: Razine kongenera polibromiranih difenil etera u serumu pasa kao mogući pokazatelji onečišćenja okoliša i izloženosti ljudi - kratko priopćenje. Vet. arhiv 89, 247-255, 2019. \\ SAŽETAK}

Iako se bromirani usporivači gorenja upotrebljavaju već šezdesetak godina, njihov je štetan učinak na životinje i moguće na ljude primijećen tek posljednjih dvadeset godina, otkad se i intenzivno proučavaju. Prisutnost usporivača gorenja u životnom prostoru ljudi čini kućne ljubimce savršenim bioindikatorskim organizmima. Među bromiranim usporivačima gorenja najviše se istražuju polibromirani difenilni eteri. Izmjerili smo koncentracije nekih kongenera polibromiranih difenilnih etera (BDE 28, BDE 47, BDE 66, BDE 100, BDE 99, BDE 85, BDE 154, BDE 153 i BDE 183) u serumu 20 pretilih kućnih pasa i 20 kućnih pasa normalne tjelesne mase. Utvrdili smo da nema statistički znakovite razlike u koncentraciji bilo kojega kongenera između dviju skupina pasa. Ukupna srednja vrijednost u serumu pretilih pasa i pasa normalne tjelesne mase bila je 0,0190 $\pm 0,0302 \mathrm{ng} / \mathrm{g}$ i 0,0112 $\pm 0,0091 \mathrm{ng} / \mathrm{g}$. Kongeneri BDE 47 i BDE 99 najčešće su prisutni u objema skupinama pasa. Nije utvrđena statistički znakovita korelacija između ukupnih BDE-a i tiroksina i tireoid stimulirajućeg hormona.

Ključne riječi: bromirani usporivači gorenja; onečišćenje; kućni ljubimci; serum; zatvoreni prostor; postojane organske onečišćujuće tvari 
